\title{
Duodenal ulcer: the villain unmasked?
}

\author{
Eradicating Helicobacter pylori will cure most patients
}

The observation "no acid, no ulcer" has dominated the medical and surgical treatment of duodenal ulcer disease and has strongly influenced research. ${ }^{1}$ Though patients with duodenal ulcer do, as a group, have a high acid output, individual values show considerable overlap with those of many people with normal acid secretion. ${ }^{2}$ Furthermore, carbenoxolone, deglycyrrhisinised liquorice, colloidal bismuth subcitrate, and sucralfate all heal ulcers without affecting acidity, through stimulating mucosal healing or enhancing cytoprotective mechanisms in some way. These observations imply that gastric acid is only one of several factors responsible for ulcer genesis.

Recently the mechanisms that protect gastric and duodenal epithelia from acid attack and other types of injury have been the subject of much research. Several have been identified, including the mucus layer, the ability of gastric and duodenal epithelia to secrete bicarbonate, ${ }^{3}$ the hydrophobic properties of gastroduodenal mucosa,${ }^{+}$the ability of mucosal cells to regenerate rapidly after insult, and the abundant blood supply of the upper gastrointestinal tract. These protective factors seem to be enhanced by prostaglandins.

Until now the only clearly understood cause of duodenal ulcer has been the Zollinger-Ellison syndrome, in which hypergastrinaemia induced by tumours causes a continuous high output of acid. Taking non-steroidal anti-inflammatory drugs, which interfere with prostaglandin synthesis, probably represents another pathogenic mechanism. These mechanisms, however, account for only a tiny proportion of duodenal ulcers, and the underlying cause of most remains unknown.

The rediscovery of Helicobacter pylori in $1983,{ }^{5}$ its isolation in pure culture, ${ }^{6}$ and subsequent research have convinced many gastroenterologists that this organism plays an important part in the pathogenesis of duodenal ulcers. ${ }^{5}$ A recent working party convened by the World Congresses of Gastroenterology concluded that $H$ pylor $i$ was the major factor in the multifactorial disease that is peptic ulcer. ${ }^{7}$ On what evidence was this conclusion based?

Since the turn of the century several reports have drawn attention to curved and spiral organisms colonising the mammalian stomach, but these organisms have usually been regarded as commensals. $H$ pylor is specifically adapted to life in the mucus that overlies gastric epithelial cells in humans and some primates. It cannot colonise other epithelial cells and so is found only in the stomach, in ectopic gastric mucosa, or in duodenal or intestinal mucosa that has undergone gastric metaplasia. The organism secretes a powerful urease, which converts endogenous intragastric urea into ammonia, thereby raising the $\mathrm{pH}$ in its immediate vicinity and protecting itself from gastric acid. ${ }^{8}$ This is probably an essential pathogenic property that enables the organism to survive in the gastric lumen during the infecting phase after ingestion. After colonisation it is found closely apposed to the apices of gastric epithelial cells where, protected by the overlying mucus layer and the alkaline secretion of the gastric cells, the $\mathrm{pH}$ is close to neutral. ${ }^{9}$ In addition to urease, ${ }^{10}$ the organism manufactures catalase, proteolytic enzymes, lipases, and exotoxins. ${ }^{112}$ These and other factors may have a pathogenic effect on the host epithelium. ${ }^{13}$ Colonisation of the stomach by $H$ pylori causes an initial acute hypochlorhydric gastritis, ${ }^{14}$ which persists for a few weeks and may then progress to a chronic active gastritis with a return of acid secretion. This chronic gastritis is the hallmark of colonisation by $H$ pylori: it is found in nearly all those infected. The vigorous but apparently ineffective chronic immune response generated by the host may eventually lead to mucosal atrophy. ${ }^{\text {is }}$

In developed countries the prevalence of helicobacter infection and associated chronic gastritis is between $20 \%$ and $40 \%,{ }^{16}$ but many studies have confirmed that $95 \%$ of patients with duodenal ulcer are colonised. ${ }^{17}$ The observation that infected people carry 20 times the risk of developing duodenal ulcer than non-infected people led to the suggestion that $H$ pylori may be responsible for duodenal ulcers. If this is the case two difficulties must be resolved. Why should a gastric infection cause duodenal disease? And why do only a few of those infected develop the disease?

\section{$H$ pylori and duodenitis}

The strong association between antral gastritis and duodenal ulcer has been recognised for many years. ${ }^{18-25}$ Duodenitis is almost invariably present in duodenal ulceration and is an even stronger predictor than gastritis, being far less common in the general population than gastritis. ${ }^{26-29}$ Furthermore, abnormalities of the duodenal mucosa persist after ulcers have healed, suggesting that duodenitis may be the primary disease, perhaps causing a breakdown in mucosal protection that creates a vulnerable area for acid attack. ${ }^{30-33}$

$H$ pylori seems to be responsible for duodenitis as well as gastritis. In five studies where $H$ pylori was sought duodenal colonisation was found in 82 out of 150 patients with duodenal ulcer $(55 \%)$, 52 out of 76 with duodenitis $(68 \%)$, but in none of 314 normal subjects. ${ }^{3+-38}$ So, although many patients harbour 
$H$ pylori in the stomach, the duodenum is colonised in only a minority. It is patients in this group who develop duodenitis ${ }^{36}$ and who appear to be at risk of a duodenal ulcer. The reason why only a small proportion of $H$ pylori carriers have duodenal infection is that the organism can infect only gastric epithelial cells so duodenal colonisation will occur only in patients whose duodenum has undergone gastric metaplasia. These findings may explain why a duodenal ulcer is nearly always associated with antral gastritis and why only a few of those with gastritis associated with $H$ pylori develop duodenal ulceration.

Exactly why duodenal mucosa undergoes metaplasia to a gastric-type epithelium is unclear. In animals the change has been induced by trauma ${ }^{39+0}$ and by hyperacidity ${ }^{41}$; in humans it is associated with hyperacidity and may represent a defensive response to a low $\mathrm{pH}^{+2+3}$

The distribution of colonisation by $H$ pylori in the stomach also influences the prevalence of ulceration. ${ }^{+}$In many patients $H$ pylori has a predilection for the antrum, leaving the body (the acid secreting part of the stomach) relatively spared. It is these patients who are at risk of developing duodenal ulcer. Recent work has shown that gastrin secretion resulting from atrophy of the body mucosa is increased in patients infected with $H$ pylori, ${ }^{+5}$ which may be reflected in an increased postprandial acid output. ${ }^{+6}$ When $H$ pylori affects the whole of the stomach - leading to a pangastritis - duodenal ulcer is less likely, perhaps because there is a tendency towards hypochlorhydria.

\section{Effects of eradicating $\boldsymbol{H}$ pylori}

$H$ pylori has the opportunity to infect the duodenum and the capability to damage the mucosa, and it is usually found at the scene of the crime-in duodenal ulcers. A hypothetical reconstruction of its role in ulcer genesis is possible, but this evidence is only circumstantial. Koch's postulates cannot be tested for ethical reasons; nevertheless, the organism can now be eradicated in most patients, and new data suggest that if this is done the natural course of duodenal ulcer disease is broken.

Unless maintenance treatment is given $82 \%$ of ulcers healed by $\mathrm{H}_{2}$ receptor antagonists relapse within one year, and 53\% of ulcers healed by colloidal bismuth subcitrate relapse over the same period (colloidal bismuth subcitrate has a limited anti-helicobacter effect). ${ }^{47}$ If $\mathrm{H}$ pylori is responsible for $95 \%$ of peptic ulcers then eradicating the organism should reduce the relapse rate to $5 \%$. Seven independent studies from different parts of the world have followed up 179 patients for one year after eradication of $H$ pylori. +8.54 The overall prospectively assessed relapse rate was $11 \%$. There are dangers in drawing conclusions from amalgamated data from different studies (some of which are described only in abstract), but the trend of results in each study was the same. The $11 \%$ relapse rate is probably an overestimate because those studied prospectively included all patients in whom $H$ pylori could not be detected one month after treatment and it may be difficult to detect small numbers of organisms after eradication treatment. When the results are analysed retrospectively - that is, when colonisation by $H$ pylori is assessed at the time of ulcer relapse rather than after treatment - the relapse rate in those in whom the organism was eliminated falls to $4 \%$. Larger and more carefully designed clinical trials need to be undertaken to confirm the benefit of eradication of $H$ pylori, to assess more effective treatment regimens, and to follow up patients over a longer period. If $H$ pylori is in fact the villain of the piece its eventual elimination will reduce the incidence of duodenal ulcer in humans by over $90 \%$.

Does this mean that attitudes towards treating duodenal ulcer should change? The international working party believes that they should. Unfortunately, there is at present no uniformly satisfactory medication for eradicating $H$ pylori. Triple treatment, using a bismuth preparation and two antibiotics, eradicated $H$ pylori in about $80 \%$ of cases, but there may be side effects: nausea, diarrhoea, sore mouth, malaise, fungal infections, and pseudomembranous colitis have been reported after treatment periods of up to a month. ${ }^{.5}$ Many people-indeed most in the developing world - harbour organisms that are resistant to nitroimidazoles, ${ }^{56} 57$ and a high proportion of those who fail to respond to treatment develop secondary resistance. ${ }^{58}$ For these reasons eradication treatment should be reserved for those with endoscopically confirmed duodenal ulcer associated with $H$ pylori who are not taking non-steroidal anti-inflammatory drugs and who present management problems (for example, frequent recurrence in a young person for whom long term treatment with $\mathrm{H}_{2}$ receptor antagonists or surgery is contemplated). After the duodenal ulcer has been healed using conventional treatment the recommended treatment is colloidal bismuth subcitrate $120 \mathrm{mg}$ four times a day, plus metronidazole $400 \mathrm{mg}$ three times a day, plus amoxycillin $500 \mathrm{mg}$ (or tetracycline hydrochloride $500 \mathrm{mg}$ ) four times a day, to be taken concurrently for two weeks. Treatment for shorter periods, or failure of compliance, may lead to resistant organisms, for which there is at present no suitable medication.

Although more work is needed before we can claim to have defeated duodenal ulcer disease, there is at last the prospect of a permanent non-surgical cure that is safe and inexpensive.

Consultant Physician, A R AXON

Gastroenterology Unit,

General Infirmary,

Leeds LS1 3EX

1 Schwarz K. Uber penetrierende Magen- und Jejunalgeschwure. Beiträge Zur Klinischen Chirurgie 1910;67:96-128.

2 Baron $\mathrm{JH}$. The relationship between basal and maximum acid output in normal subjects and patients with duodenal ulcer. Clin Sci 1963;24:357-70.

3 Shorrock CJ, Rees WDW. Gastroduodenal bicarbonate secretion. In: Salmon PR, ed. Key developments in gastroenterology. Chichester: John Wiley, 1988:171-87.

+ Lichtenberg L.M, Graziani LA, Dial EJ, et al. Role of surface active phospholipids in gastric crtoprotection. Science 1983;219:1327-9.

5 Warren JR, Marshall B. Unidentified curved bacilli on gastric epithelium in active chronic gastritis. Lancet 1983:i:1273-5.

6 Marshall BJ, Warren JR. Unidentified curved bacilli in the stomach of patients with gastritis and peptic ulceration. Lancet 1984;i:1311-4.

7 Tytgat GNJ, Axon ATR, Dixon MF, Graham DY, Lee A, Marshall BJ. Helicobacter pylori: causal agent in peptic ulcer disease? In: Working party reports. World Congresses of Gastroenterology, 26-31 August 1990. Oxford: Blackwell Scientific, 1990:36-45.

8 Marshall BJ, Barrett LJ, Prakash C, McCallum RW, Guerrant RL. Urea protects Helicobacter (Campylobacter) pylori from the bactericidal effect of acid. Gastroenterology 1990;99:697-702.

9 Rees WDW, Turnberg LA. Mechanisms of gastric mucosal protection: a role for the mucusbicarbonate barrier. Clin Sci 1982;62:343-8.

10 Megraud F. Campylobacter pylori: enzymes. In: Rathbone BJ, Heatley RV, eds. Campylobacter pylori and gastroduodenal disease. Oxford: Blackwell Scientific, 1989:39-47.

11 Figura N, Guglielmetti P, Rossolini A, et al. Cytotoxin production by Campylobacter pylori strains isolated from patients with peptic ulcers and from patients with chronic gastritis only. $f$ Clin Microbiol 1989;27:225-6.

12 Cave DR, Vargas M. Effect of a Campylobacter pylori protein on acid secretion by parietal cells. Lancet 1989;ii: 187-9.

13 Malfertheiner P, Ditschuneit H, eds. Pathogenic mechanisms of H pylori. In: Helicobacter pylori, gastritis and peptic ulcer. Berlin and Heidelberg: Springer-Verlag, 1990:63-127.

It Hunt RH. Campylobacter pylori and spontaneous hypochlorhydria. In: Rathbone BJ, Heatley RV, eds. Campvlohacter pylori and gastroduodenal disease. Oxford: Blackwell Scientific, 1989:176-84.

15 Misiewic. JJ. Tytgat GNJ, Goodwin CS, et al. The Sydney system: a new classification of gastritis. In: Working Party reports. World Congresses of Gastroenterologv, 26-31 August, 1990. Oxford: Blackwell Scientific, 1990:1-10.

16 Dwyer B, Kaldor J, Tee W, Raios $\mathrm{K}$. The prevalence of Campylobacter pylori in human populations. In: Rathbone BJ, Heatlev RV, eds. Campylobacter pylori and gastroduodenal disease. Oxford: Blackwell Scientific, 1989: 190-6.

17 Wyatt J1. Campylobacter pylori, duodenitis and duodenal ulceration. In: Rathbone BJ, Heatley RV, eds. Campylobacter pylori and gastroduodenal disease. Oxford: Blackwell Scientific, 1989:11724.

18 Mackay IR, Hislop (i. Chronic gastritis and gastric ulcer. Gut 1966;7:228-33.

19 Schrager J, Spink R, Mitra S. The antrum in patients with duodenal and gastric ulcers. Gut 1967;8:497-508.

20 Nielsen $\mathrm{H}()$, Munoz J, Kronborg O, Andersen D. The antrum in duodenal ulcer patients. Scand $\mathcal{F}$ Gastrocinterol 1981;16:491-3.

21 Gear ML, Truelove SC, Whitehead R. Gastric ulcer and gastritis. Gut 1971;12:639-45.

22 Earlam RJ, Amerigo J, Kakavoulis T, Pollock DJ. Histological appearances of oesophagus, antrum and duodenum and their correlation with symptoms in patients with duodenal ulcer. (iu 1985:26:95-100. 
23 Hui W-M, Lam A-K, Ho J, et al. Chronic antral gastritis in duodenal ulcer. Natural history and treatment with prostaglandin $\mathrm{E}$ 1. (iustroenterologv 1986;91:1095-101.

24 Cheli R, Giacosa A. Duodenal ulcer and chronic gastritis. Endoscopy 1986;18:125-6.

5 . Moore SC, Malgelada J-R, Shorter RG, Zinmeister AR. Interrelationship among gastric mucosal morphology, secretion, and motility in peptic ulcer disease. Dig Dis $S_{c i} 1986 ; 31: 673-83$.

26 Joffe SN, Lee FD, Blumgart LH. Duodenitis. Clinics in Gastroenterology 1978;7:635-50.

27 Meikle DD, Taylor KB. Truelove SC, Whitehead R. Gastritis duodenitis, and circulating levels of gastrin in duodenal ulcer before and after vagotomy. Gut 1976;17:719-28.

28 Hasan $M$. Sircus W, Ferguson $A$. Duodenal mucosal architecture in non-specific and ulcer associated duodenitis. (iut 1981;22:637-41

29 Cotton PB, Price AB, Tighe JR, Beales JSM. Preliminary evaluation of "duodenitis" by endoscopy and biopsy. BMF 1973;iii:430-3.

30) Fullman H, Deventer (iV, Schneidman D, Walsh J, Elashoff J, Weinstein W. "Healed" duodenal ulcers are histologically ill. Gastroenterology 1985;88:1390.

31 Moshall MG, Gregory MA, Pillay C, Pitaels JM. Does the duodenal cell ever return to normal? A comparison between treatment with cimetidine and DeNol. Scand f Gastroenterol 1979;14 (suppl $56): 48-51$

32 Paoluzi P, Pallone F, Zaccardelli E, Ripoli F, Marcheggiano A, Carratu R. Outcome of ulcerassociated duodenitis after short-term medical treatment. Dig Dis Sci 1985;30:624-9.

33 Johnson BJ, Reed I, Ali MH. Campylobacter-like organisms in duodenal and antral endoscopic biopsies: relationship to inflammation. Gut 1984:25:1132-7.

34 Steer HW. Surface morphology of the gastroduodenal mucosa in duodenal ulceration. (iut 1984;25:1203-10

35 Wyatt JI, Rathbone BJ, Dixon MF, et al. Campylobacter pyloridis and acid-induced gastric metaplasia in the pathogenesis of duodenitis. F Clin Pathol 1987;40:841-8.

36 Bode G, Malfertheiner P, Ditschuneit H. Pathogenetic implications of ultrastructural findings in Campylobacter pylori related gastroduodenal disease. Scand J Gastroenterol 1988;23(suppl $142): 25-35$.

37 Caselli M. Bovolenta MR, Aleotti A, et al. Epithelial morphology of duodenal bulb and campylobacter-like organisms. I Submicrosc Cytol Pathol 1988;20:237-42.

38 Florey HW, Harding HE. The healing of artificial defects of the duodenal mucosa. Foumal of Pathology and Bacteriology 1935;40:211-8.

39 Florey HW, Jennings MA, Jennings DA, O'Connor RC. The reaction of the intestine of the pig to gastric juice. Fournal of Pathology and Bacteriologv 1939;49:105-23.

40 Rhodes J. Experimental production of gastric epithelium in the duodenum. (iut 1964;5:454-8.

11 James AJ. (iastric epithelium in the duodenum. ( iut 1964;5:285-94

42 Patrick WJA, Denham D, Forrest APM. Mucus change in the human duodenum: a light and elecron microscopic study and correlation with disease and gastric acid secretion. (iuc 1974;:25:767-76.

43 Sipponen P, Deppala K, Aarynen M, Kettunen P. Chronic gastritis and gastroduodenal ulcer: case-control study on risk of coexisting duodenal or gastric ulcer in patients with gastritis. (ith 1989;30:922-9.

44 Levi S, Beardshall K, Haddad G, Playford R, Ghosh P, Calam J. Campylobacter pylori and duodenal ulcers: the gastrin link. Lancet 1989;i:1167-8.

45 McColl KEL, Fullarton GM, Nujumi AME, Macdonald AM, Brown IL, Hilditch TE. Lowered gastrin and gastric acidity after eradication of Campylobacter pvlori in duodenal ulcer. Lancet 1989;ii:499-500.

46 Coghlan J( , Tobin A, O'Morain C. Campylobacter pylori and ulcer treatment. In: Rathbone BJ, Heatley RV, eds. Campylobacter pylori and gastroduodenal disease. Oxford: Blackwell Scientific, 1989:232-45.

47 Coghlan JG, Gilligan D, Humphries H, et al. Campylobacter pylori and recurrence of duodenal ulcers - a 12 months follow-un studv. Lancet 1987;ii:1109-11.

48 Marshall BJ, Goodwin CS, Warren JR, et al. Prospective double-blind trial of duodenal ulcer relapse after eradication of Campylobacter pylori. L.ancet 1988;ii:1437-41.

49 Smith AC, Price AB, Borriello P, Levi AJ. A comparison of ranitidine and tripotassium dicitratobismuthate (TDB) in relapse rates of duodenal ulcer. The role of Campylobacter pylori (C.p.). (Fastroenterology 1988;94:A431

50 Rauws EAJ, Tytgat GNJ. Eradication of H pylori cures duodenal ulcer. Lancet 1990;335:1233-5.

51 George L, Hyland L, Morgan A, et al. Smoking does not contribute to duodenal ulcer relapse after eradication. Gastroenterologv 1990;98:A48.

52 Patchett S, O'Riordan TO, Leen $\mathrm{E}$, Keane $\mathrm{C}$, O'Moraine $\mathrm{CO}$. A prospective study of $\mathrm{H}$ pylori eradication in duodenal ulcer. Gastroenterology 1990;989:A 104.

53 Lambert JR, Borromeo M, Korman MG, Hansky J, Eaves ER. Effect of colloidal bismuth (DeNol) on healing and relapse of duodenal ulcers - role of Campylobacter pyloridis. Gastroenterologv 1987;92:1489.

54 Borody TJ, Cole P, Noonan S, et al. Recurrence of duodenal ulcer and Campylobacter pylor infection after eradication. Med $\mathcal{F}$ A ust 1989;151:431-5.

55 Glupczynski Y, Bourdeaux L, Verhas M, et al. Short-term double or triple oral drug treatment of Helicobacter pylori $(\mathrm{Hp})$ in Central Africa. (iastroenterologv 1990;98:A48.

56 Glupczynski Y Buretta A. De Koster $\mathrm{F}$, et al Metronidazole resistance in Helicobacter pylori. Lancet 1990;335:976-7.

57 Glupczynski Y. In vitro susceptibility of Helicobacter pylori to antibiotics and bismuth salts and the importance of acquired resistance to antibiotics in treatment failures of $\mathrm{H}$ pylori infection. In Malfertheiner P, Ditschuneit H, eds. Helicobacter pylori, gastritis and peptic ulcer. Berlin and Heidelberg: Springer-Verlag, 1990:49-58.

\section{HIV infection in children}

\section{Millions will suffer}

By the end of next year, the World Health Organisation predicts that, world wide, over one million children will be infected with HIV, half of whom will have AIDS. ${ }^{\prime}$ This could increase infant and child mortality by as much as one third, making AIDS a major cause of death among children by the end of the century. Next week a conference will be devoted to the topic, organised jointly by the National Children's Bureau and the National AIDS Trust. Speakers will be urging closer cooperation between the statutory and voluntary sectors in caring for children with HIV infection. How much is known medically about this group?

The first reports of paediatric AIDS concentrated on terminally ill children who had been infected with HIV by their mothers ("vertical transmission"). ${ }^{2-4}$ Now the full range and natural course of HIV disease in children are emerging. ${ }^{56}$ Early diagnosis of HIV infection is essential because children may develop symptoms suddenly and have a high mortality. The mean incubation period for children infected with HIV is $4 \cdot 7$ years, but for those under 5 years old this is reduced to $2 \cdot 3$ years. The opportunity for effective intervention is therefore small.

Of those infants who acquire HIV infection from their mothers, one in four will develop AIDS in the first year of life; four fifths will have developed AIDS by the end of their fourth year. ${ }^{78}$ The European collaborative study reported recently that an estimated $83 \%$ of infected children show laboratory or clinical evidence of HIV infection by 6 months of age." Twenty six per cent had progressed to AIDS by 12 months, and the mortality from HIV related disease was $17 \%$. Subsequently, the disease progressed more slowly, with most children remaining stable during the second year of life. ${ }^{9}$
How may HIV infection be diagnosed in young children, in whom maternal antibodies may persist for up to 18 months? Tests that document infection, such as HIV antigen tests or culture, are not routinely available and may yield false negative results. $^{10}$ Hypergammaglobulinaemia has been suggested as an early and sensitive indicator of HIV infection, ${ }^{11}$ and without more definitive tests could be used as a surrogate test for HIV infection in children in whom chronic infections have been excluded.

With recent advances in managing adults infected with HIV, paediatricians will want to know which children might benefit from treatment. Factors correlating with or contributing to progression of disease have been evaluated in several cohorts. Two studies found that persistent antigenaemia with loss of core antibody was associated with poor outcome in children. ${ }^{12} 13$ Though measures of viral activity (core antigen levels) had little predictive power, tests of immune activation (serum neopterin and $\beta_{2}$ microglobulin concentrations) and immune deficits (absolute numbers of CD4+ $\mathrm{T}$ cells) were shown to predict accurately the progression to AIDS in infants born to mothers infected with HIV (C Courpotin et al, C Tuset et al, VIth international conference on AIDS, San Francisco, 1990). There is, however, a need to establish the normal range of serum concentrations of neopterin and $\beta_{2}$ microglobulin in children.

Although treatment with zidovudine prolongs survival in adults with low $\mathrm{CD} 4+$ counts $^{14}$ no placebo controlled trials have been done in children. Though most paediatricians would give zidovudine to children with AIDS, the optimal dosage, route, and frequency of delivery have not been determined. Reports of early phase I trials in children 